\title{
Aspects of the Thermo-Mechanical Evolution of the Platform of Florianópolis and the Pelotas Basin
}

Correa, S.A.S*., LASG-UNIPAMPA; Correa, S., LASG-UNIPAMPA; Silva, V.L., LASG-UNIPAMPA; Lima, M.V.A.G., LASG- UNIPAMPA; Guadagnin, F., LASG-UNIPAMPA

\section{Copyright 2019, SBGf - Sociedade Brasileira de Geofísica}

This paper was prepared for presentation during the $16^{\text {th }}$ International Congress of the Brazilian Geophysical Society held in Rio de Janeiro, Brazil, 19-22 August 2019.

Contents of this paper were reviewed by the Technical Committee of the $16^{\text {th }}$ International Congress of the Brazilian Geophysical Society and do not necessarily represent any position of the SBGf, its officers or members. Electronic reproduction or storage of any Geophysical Society is prohibited.

\begin{abstract}
Passive margin basins are influenced by two different subsidence patterns, mechanical subsidence caused by crustal stretching and thermal subsidence caused by thermal gradient reduction. Backstripping consists of applying an isostatic balance that allows isolating subsidence caused by sediments from the total subsidence and analyzes the tectonic component. In this work, subsidence analysis is performed in a well-marked flux, using information and physical properties earned by borehole profiles. Results revealed aspects and specificities of processes, which have already been advocated in the other basins of southeastern Brazilian continental margin.
\end{abstract}

\section{Introduction}

The generation of sedimentary basins requires the action of subsidence processes in a given region for a certain period of time (eg, Kusnir \& Ziegler, 1992). As a result, there is a substrate lowering (and / or elevation of adjacent regions), which can sometimes be found in lower regions to the stratigraphic base level position, causing sedimentary deposition, which can be preserved or not (Catuneanu et al., 2009). Nine large sedimentary basins are distributed along the eastern Brazilian continental margin. The filling of these basins consists of sediments originating from the rift phase (lacustrine and continental) underlies to upper / tertiary cretaceous marine carbonate platforms and sediments accumulated during the drift phase. The Mesozoic sediments of the Pelotas Basin overlap Precambrian crystalline rocks, Paleozoic rocks of the Paraná Basin, and continental and transitional crustal volcanic rocks (Abreu, 1998). Watts \& Ryan (1976), Steckler \& Watts (1978) and Watts (1981) establish that interest of sedimentary basins historical analysis consists of some systematical steps, which allow estimates on qualitative way the initial porosity of sedimentary rocks, uncompactation, sedimentation rate, subsidence rate, among other parameters. Such a set of processes make up the tool known as backstripping, which consists of the application of isostatic equilibrium conditions - in situ - to a given sediment load. Sedimentation on a continental Atlantic margin constitutes a load on the lithosphere by the action of superimposed weight, and consequently crustal archment.
Studies on the geometry of deformation suggest that the lithosphere will react to such local loads by point isostasy, or by flexural load of a rigid crust. The application of the backstripping technique to 1D sections of sedimentary basins allows the reconstruction of the corrected subsidence curve for the degree of compaction and for the removal of the influence of the superimposed sedimentary load, called tectonic subsidence (Chang et al., 1992). The purpose of this work is to contribute with information already available from the subsidence analysis in curves for a set of wells (Lee et al., 2016), which record the tectono-sedimentary evolution of the Pelotas Basin (Figure 1) from of its rifting phase.

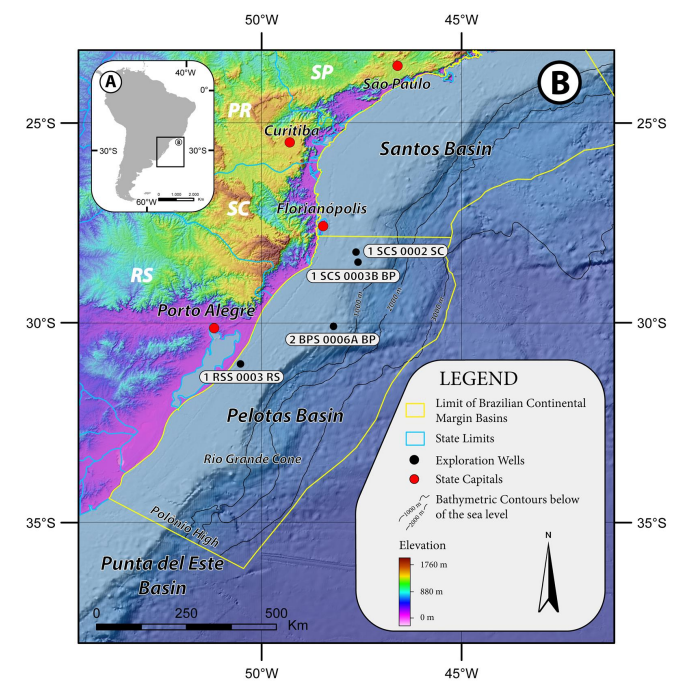

Figure 1 - Location map of the wells used for this study.

\section{Method}

The backstripping technique was developed in the 1970s and is widespread today (eg Xie \& Heller, 2009; Contreras et al., 2010, Lee et al., 2016). Watts \& Ryan (1976) borrowed from the Sleep Legacy (1971), to study the dynamic evolution of sedimentary packages occurring on the East Coast and the Gulf of Lion. Later Steckler \& Watts (1978) use the same backstripping theoretical framework on the continental margin of New York, USA. The latter correlate biostratigraphic data from a set of wells to determine the influence of the sedimentary load on total subsidence, from which tectonic subsidence is inferred. Basin Vis 1.0 software (Lee et al., 2016) was used to perform the treatment, processing and results. 
The modeling routine is implemented in MatLab, whose source code is open and consists of known numerical techniques of interpolation (linear, splines and kriging) that are able to perform subsidence analysis in its classical form using the backstripping technique and reconstructing the deposition surfaces for each interval depending on the data population. In the data configuration a new project is started, defining the extension of study area, stratigraphic units and geological ages. An additional condition also allows the user to define the edges of the basin In the wells window are inserted cataloging information and a list of top depths for the top depths and thickness for the stratigraphic units. The subsidence analysis allows the user to inspect the numerical results of subsidence in a well, in the spreadsheet form. In addition, the depths of tectonic subsidence.

\section{Results}

The analysis is restricted to wells that provide quantitative data of stratigraphic thickness, deposition ages, and, where the tectonic configuration is well established. The same sedimentary basin may be subject to several phases of subsidence due to the change of tectonic configuration. Thus, it is attempted to identify such phases (TS subsidence trend) for each stage of tectonic configuration. Only the wells that reach the basement are considered for the accomplishment of this work. The information is entered based on the composite profile of the wells. The deposition ages for the stratigraphic horizons are in accordance with the stratigraphic chart proposed by Bueno et al. (2007). The parameters used for the calculation of subsidence depend on the type of sediment (density), the genetic framework of the rock (porosity and degree of compaction), and were adapted by Contreras et al. (2010). The following figures show the numerical subsidence (tectonics and basement) as a function of time and the rates related to these quantities.

The tectonic subsidence (Equation 1) is calculated by obtaining solutions that correspond to the isostatic equilibrium between the lithospheric column in a sedimentary basin, and the same column in which the superimposed sedimentary load is replaced by water (Steckler \& Watts, 1978):

$$
Y(t)=S^{*}(t)\left(\frac{\rho_{m}-\rho_{S}(t)}{\rho_{m}-\rho_{w}}\right)-\Delta_{S L}(t)\left(\frac{\rho_{m}}{\rho_{m}-\rho_{w}}\right)^{1},
$$

Where $Y(t)$, is the basement depth in the absence of loads on the crust, $S^{*}(t)$ is the uncompacted sediments thickness for the deposition time, $\rho_{m}, \rho_{s}(t)$ and $\rho_{w}$ the mantle density, sediment density and water density. $\Delta_{S L}(t)$ is the relative variation among the sea level at the deposition time and the current time.

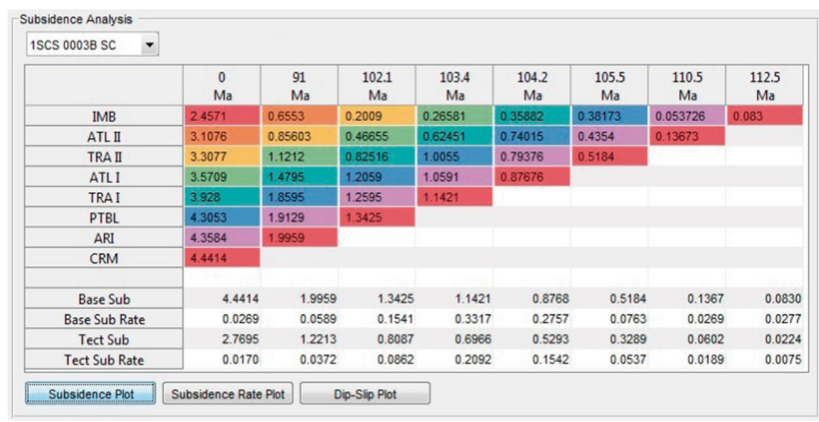

Figure 2 - Numerical subsidence for the well SC-03.

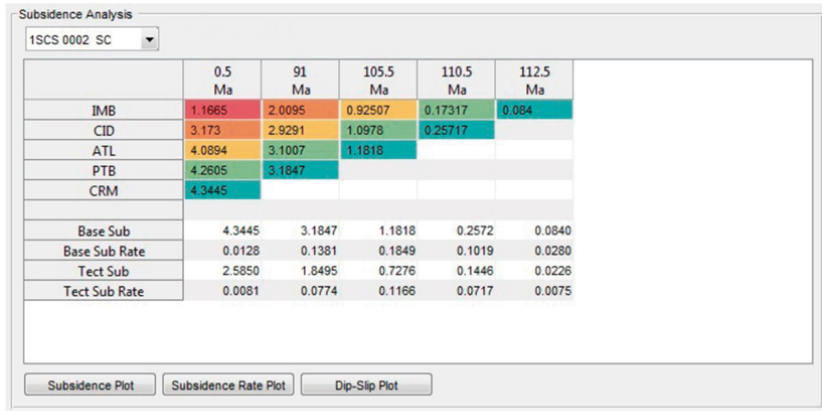

Figure 3-Numerical subsidence for the well SC-02.

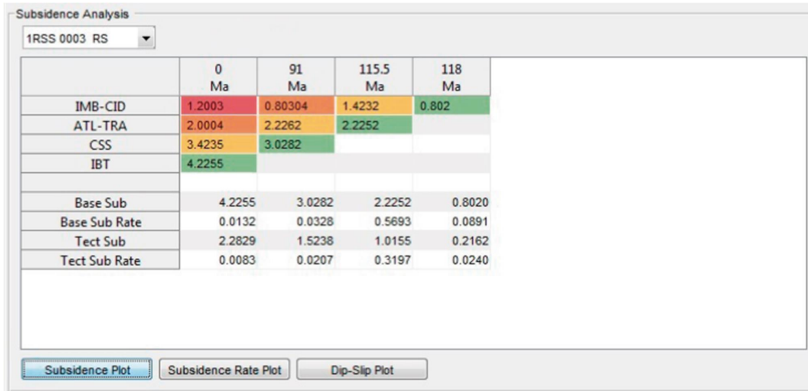

Figure 4 - Numerical subsidence for the well RS-03.

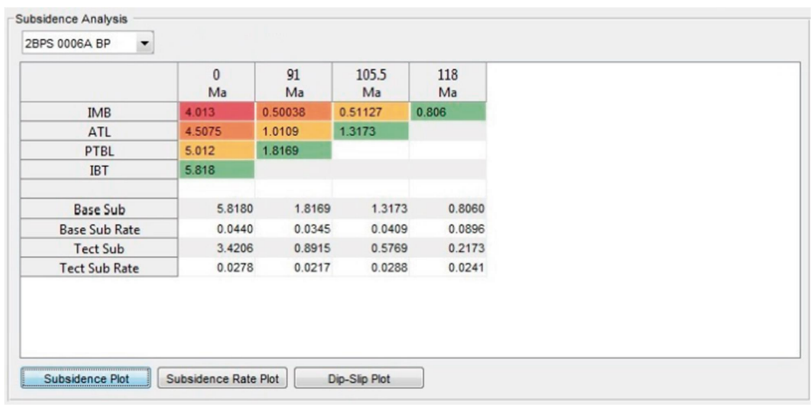

Figure 5 - Numerical subsidence for the well BP-06. 


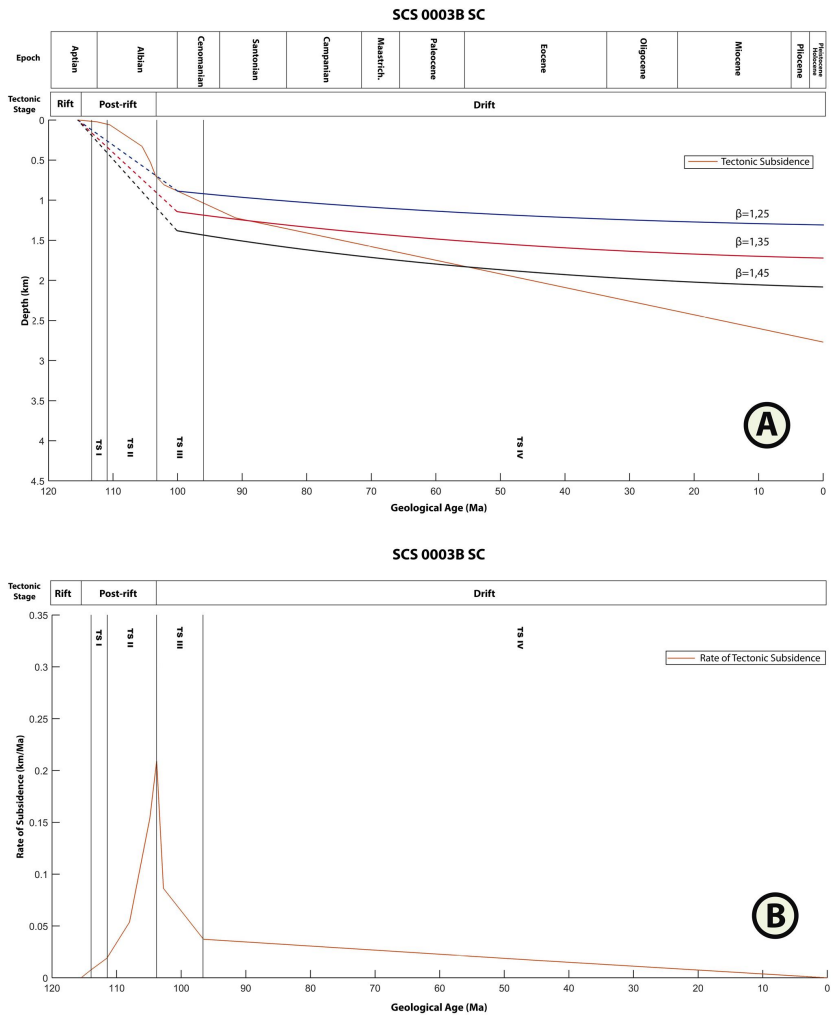

Figure 6 - Subsidence curve for the well SC-03. Best fit for stretching factor $\beta=1,35(A)$ related subsidence rate $(B)$.

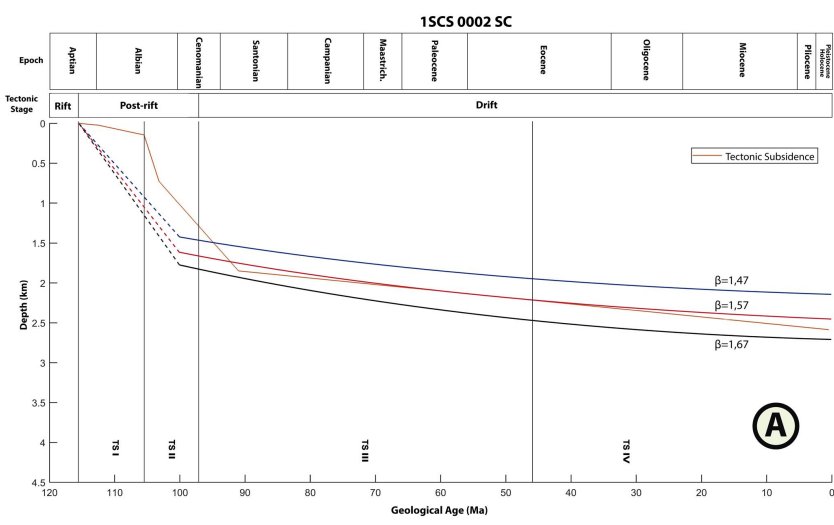

$15 \mathrm{ScS} 0002 \mathrm{sc}$

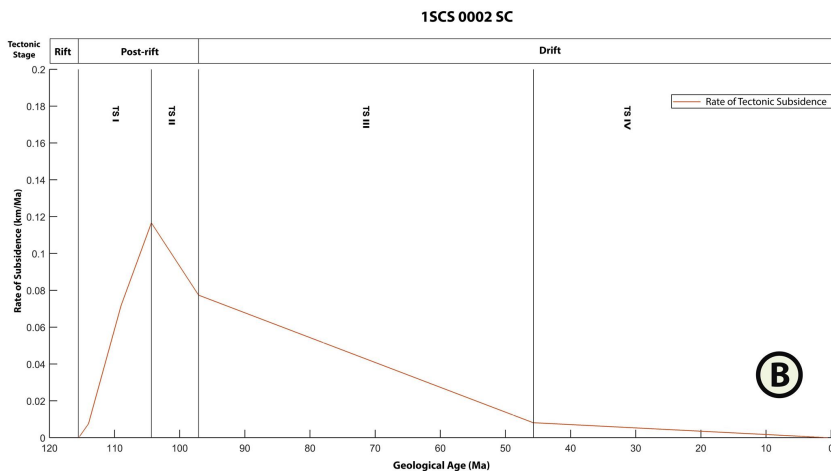

Figure 7 - Subsidence curve for the well SC-02. Best fit for stretching factor $\beta=1,57$ (A) related subsidence rate.

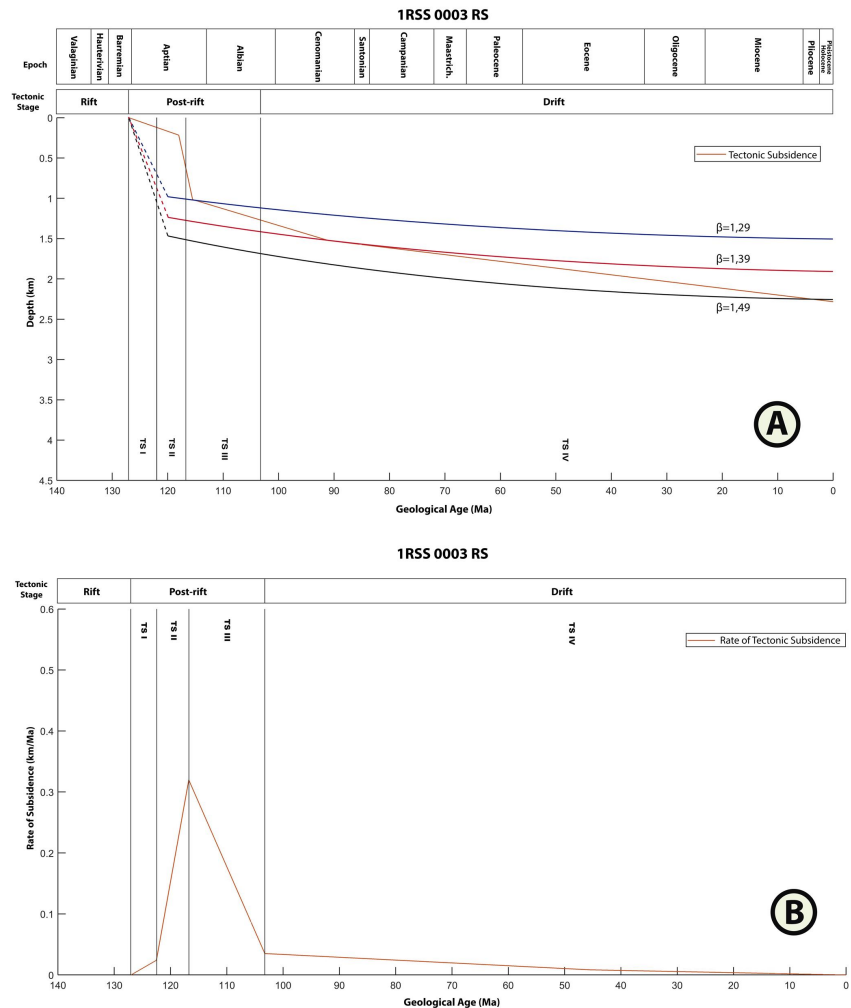

Figure 8 - Subsidence curve for the well RS-03. Best fit for stretching factor $\beta=1,39(A)$ related subsidence rate $(B)$.
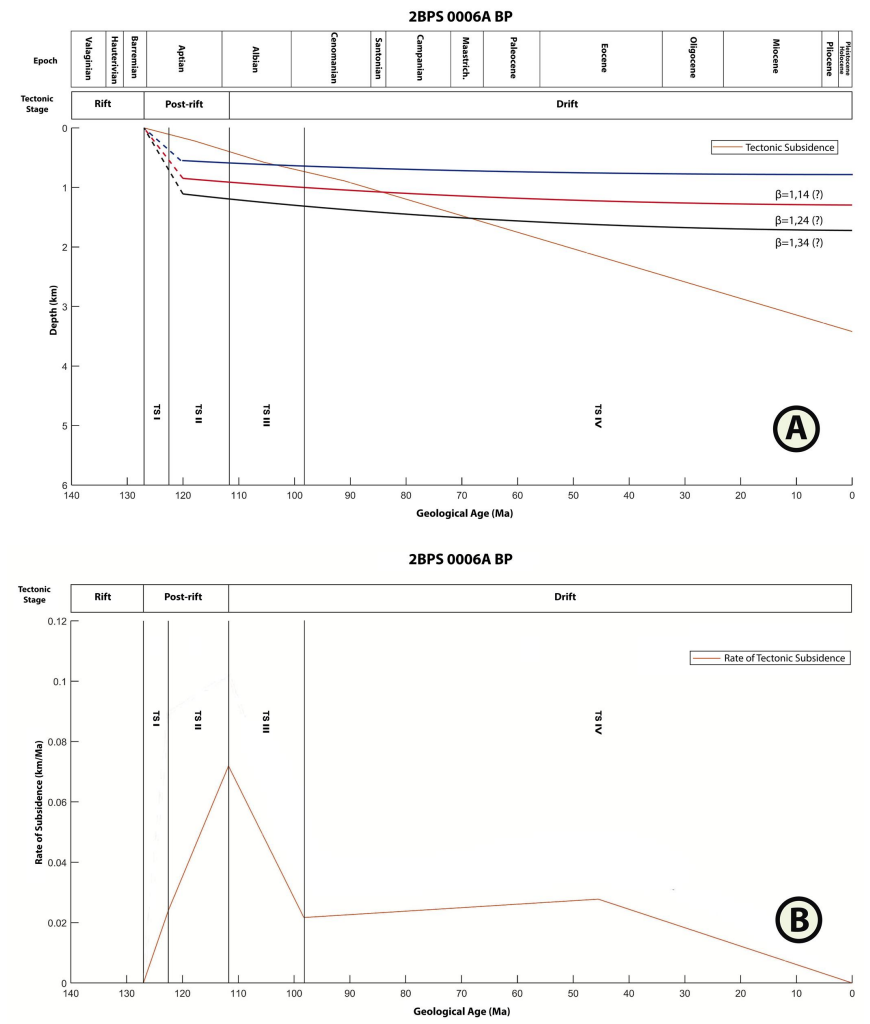

Figure 8 - Subsidence curve for the well BP-06. Best fit for stretching factor $\beta=1,24($ ?) $(A)$ related subsidence rate $(B)$. 
In general, it is difficult to make considerations about the sediment thickness of the sin-rift phase, since only one of the wells used registers the sedimentation typical of this phase. The subsidence pattern I (TS I) indicates that the Pelotas basin was subject to a growing regime of tectonic subsidence for this period (Neo-aptian / Eo-Albian), with the largest component being mechanical subsidence, associated with the reminiscent rift phase. This stage is tectonically active, with normal faults, crustal stretching and thinning due to the mantle dynamics, intense volcanic activity and high thermal flow (Fontana, 1987). The subsidence pattern II (TS II) characterizes the initial postrift tectonic stage. At this stage the subsidence rate has strictly increasing behavior, varying abruptly in the few million years (10Ma) (Eo-Albian / Neo-Albian). After the rupture of the brittle crust and consequent rise to higher levels in the lithosphere, warmer and less dense, a process of restoration of the thermodynamic equilibrium followed, in which older rocks begin to drag with themselves the thin crust that constituted the floor of the newly formed basin (Fontana, 1987). Due to lithospheric cooling, the major subsidence component at this stage is thermal, amplified by the rock load of the Curumim volcanic suite and the extensive continental (deltaic and fluviolacustrine) deposits that migrate towards down-dip basin down-dip. The subsidence pattern III (TS III) shows the equilibrium stage reached evidenced by the gradual fall in the subsidence rate (5Ma) (Neo-aptian / Albian). The entire rift / post-rift sequence begin to be buried under a thick sedimentary wedge. In this same place, a hinge zone is implanted where the juxtaposition of volcanic rocks occurs on the crust, due to the rheological difference and the overloading action on the metamorphic basement (Fontana, 1987). The IV subsidence pattern (TS IV) characterizes the Atlantic margin drift stage. From the Miocene it becomes more active in the basin the flexural subsidence component, with few action of thermal subsidence. It is also where most of the sedimentary deposition occurs, accentuated by coastal onlaps, prominent since the Paleocene (Fontana, 1987).

\section{Discussion and Conclusions}

The tectonic subsidence has a quasi-exponential form, and is quite similar to the wells, considering that this basin is in fact subject to varying tectonic conditions internally (Martins-Neto et al., 2006). The SC-03, SC-02 and BP-06 (northern subbasin) wells present a maximum tectonic subsidence rate of $0.2092,0.1116$ and $0.0288 \mathrm{~km} / \mathrm{Ma}$ respectively (Figs. 2, 3 and 5) The RS-03 well (Fig.4) (south subbasin) has a tectonic subsidence of 1.5 times greater of the order of $0.32 \mathrm{~km} / \mathrm{Ma}$.
There is an internal gradient of subsidence for the northern sub-basin. Subsidence has a maximum when closer to the platform slope break region (SC03-0.21 km / $\mathrm{Ma}$, Figure 2) and a minimum (SC02-0.12 Km / Ma, Figure 3 ), which is more internal, caused by precisely by the flexural action by addition of sedimentary load, acting as a sediment receiver from the extension phase.

The fit verified for two of the curves (SC-02 and RS-03) between the uniform stretching (pure shear) model and the tectonic subsidence, suggests that after reaching the equilibrium condition in the crust, the thermal subsidence gradual and practically incipient way. Even lower values than usual $(\beta=1.57,1.39)$ are able to produce high heat flux by raising the isotherm from $1300^{\circ} \mathrm{C}$ to higher crustal levels (Fontana, 1990).

The curve mismatch occurs due to the interference of the flexural component of tectonic subsidence. It may also mean that the uniform crustal stretching model is subject to limitations of which local tectonics does not have a solely traction component, and thus the shear is not necessarily pure. By extension, the stretch is not uniform, and the initial subsidence up to the rift installation stage is not instantaneous.

\section{Acknowledgements}

The Brazilian Society of Geophysics for the Financing and the Support to this Research Project. To LASG from the Universidade Federal do Pampa for the structure and support. 


\section{References}

ABREU, V. S. 1998 Geologic Evolution of Conjugate Volcanic Passive Margins: Pelotas Basin (Brazil) and offshore Namibia (Africa); implication for global sea-level changes. Rice University, Houston, Texas, Tese de Doutorado, $354 \mathrm{p}$.

BUENO, G.V.; ZACHARIAS, A.A.; OREIRO, S.G.; CUPERTINO, J.A.; FALKENHEIN, F.U.H.; NETO, M.A.M. 2007. Bacia de Pelotas. Boletim de Geociências da Petrobras, 15(2): 551-559.

CATUNEANU, O.; ABREU, V.; BHATTACHARYA, J. P.; BLUM, M. D.; DALRYMPLE, R. W.; ERIKSSON, P. G.; FIELDING, CHRISTOPHER R.; FISHER, W. L.; GALLOWAY, W. E.; GIBLING, M. R.; GILES, K. A.; HOLBROOK, J. M.; JORDAN, R.; KENDALL, C. G. ST.C.; MACURDA, B.; MARTINSEN, O. J.; MIALL, A. D.; NEAL, J.E.; NUMMEDAL, D.; POMAR, L.;

POSAMENTIER, H. W.; PRATT, B. R.; SARG, J. F.; SHANLEY, K. W.; STEEL, R. J.; STRASSER, A.; TUCKER, M. E.; AND WINKER, C., 2009. Towards the standardization of sequence stratigraphy. Earth-Science Reviews, 94, 98-100.

CHANG, H.K.; KOWSMANN, R.O.; FIGUEIREDO,

A.M.F.; BENDER, A.A. 1992. Tectonics and stratigraphy of the East Brazil Rift System: An Overview. Elsevier Science Publishers B.V., Amsterdam. Tectonophysics, 213, 97-138.

CONTRERAS,J.; ZÜHLKE, R.;BOWMAN, S.; BECHSTÄDT, T. 2010. Seismic stratigraphy and subsidence analysis of the Southern Brazilian Margin (Campos, Santos and Pelotas basins).Elsevier Science Publishers B.V., Amsterdam. Marine Petroleum \& Geology, 27, 1952-1980.

FONTANA, R.L. 1987. Desenvolvimento Termomecânico da Bacia de Pelotas e parte sul da Plataforma de Florianópolis. UFOP. Dissertação de Mestrado em Geologia Estrutural.

FONTANA, R.L. 1990. Desenvolvimento Termomecânico da Bacia de Pelotas e parte sul da Plataforma de Florianópolis. In: GABAGLIA, G.P.R. \& MILANI, E.J. (eds.). Origem e Evolução de Bacias Sedimentares.

Petrobras. p. 377-400. 1990.

KUSNIR, N.J.; ZIEGLER P.A., 1992. The Mechanics of Continental Extension and sedimentary basin formation: a simple pure-shear flexural cantilever model. Elsevier Science Publishers B.V., Amsterdam Tectonophysics, 215, 117-131.

LEE, E.Y.; NOVOTNY, J.; WAGREICH, M. BasinVis 1.0: a MATLAB-based program for sedimentary basin subsidence analysis and visualization. Elsevier Science Publishers B.V., Amsterdam. Computers \& Geosciences, 91: 119-127, 2016.

MARTINS-NETO, M. A.; FALKENHEIN, F. U. H.; CUPERTINO, J. A.; MARQUES, E. J. J.; BUENO, G. V.; PORSCHE, E.; BARBOSA, M. S. C.; GOMES, N. S.; EV, L. F. \& LEITE, M. G. P. 2006. Breakup propagation in Pelotas Basin, southern Brazil. In: Congresso Brasileiro de Geologia, 43.
STECKLER, M.S.; WATTS, A.B.1978. Subsidence of the Atlantic-type continental margin off New York. Earth and Planetary Science Letters. 41 (1), 1-13.

WATTS, A.B., 1981. The U.S. Atlantic Continental Margin: Subsidence History, Crustal Structure and Thermal Evolution. American Association of Petroleum Geologists Education Course Note Series, v. 19, p 2-1 to 2-15.

WATTS, A.B.; RYAN, W.B.F. 1976. Flexure of the lithosphere and continental margin basins. Elsevier Science Publishers B.V., AmsterdamTectonophysics, 36, p. $25-44$.

WATTS, A.B.; STECKLER, M.S. 1981. Subsidence and Tectonics of Atlantic-type continental margins..In Oceanologica Acta, preceedings $26^{\text {th }}$ international Geological Congress, Geology of Continental Margins Symposium. pg. 143-153. Paris.

XIE, X.; HELLER, P.L. 2009. Plate Tectonics and Basin Subsidence History. Geological Society of American Bulletin, 121, 55-64. 